\title{
The Gower Street cuckoos
}

It's a growing problem.

\begin{abstract}
Joe Dunckley
Charles Quackenbush is a prodigy. He doesn't look his 39 years, and already The Daily Mail has credited him with seven miracle cures for cancer, one for each of his years as professor at the Midwitch Institute. He looks up from his computer to sigh in unison with his 460 fellow travellers, as a crackly voice announces that all Crossrail services have been suspended, and that the train will terminate at Tottenham Court Road. Thank God the tunnel has Wi-Fi.
\end{abstract}

Charles adjusts the bag between his feet, and presses himself to the carriage wall, in an attempt to gain some working space among those standing. All he can do is return to the device before him, and the online lab notebook that he is searching for clues. He is still trying to solve the problems that his graduate student has been having, and is furious with his lack of success.

Let me explain. Charles's student is trying to treat some glioma cells with a drug that should inhibit the cell cycle. This treatment is just a preliminary step in a bigger experiment, and the activity of the drug on the cells has been known for decades. The pesky cells, however, are showing utter disregard for orthodox science, and stubbornly reproduce like rabbits.

The student did not need Charles's prompting to try the experiment with a new stock of drug from the concentrate, with fresh culture media, and finally with new cells from the frozen stock. None had made the slightest difference. It was at this point that Charles came in. $\mathrm{He}$ had bought a new set of media ingredients, had his pipettes calibrated and the tissue culture incubators serviced, and treated the cells to glass Petri dishes begged and borrowed from a colleague. Finally, two weeks ago, he had actually attempted to perform the experiment himself. After his inevitable failure he was at least consoled by issuing the order that the pests be disposed of. Stumped, he had sent a vial of frozen cells to colleagues in Sweden, and another to the department's sequencing guys, in the hope that somebody else might solve the problem for him.

Charles had hoped that the matter would all go away after Sarah had left. It had been a blow having to dismiss his technician: she was skilled, hardworking and thorough. But towards the end, he had received ever more frequent reports of infractions - flooding the laboratory by leaving the water purifier on over night; allowing a fungal contamination to wipe out all the flasks of neuroblastoma cells; and finally, Charles had found her at the tissue culture hood, glassy eyed and filling an incubator with nearly 60 flasks of glioma cells.

Charles moves on, and the uneasy feeling that has been competing with anger for space in his head grabs a lead. Either one of his students has totally destroyed his records, or something is very wrong with his inventory of liquid-nitrogen frozen cells. The page should list first- and second-generation stocks of a dozen different cell types going back to the start of Charles's 10 years as a lab leader, but instead lists four dozen vials of glioma cells. Like the 'regular save' function on his notebook, five vials had been frozen consistently at three-day intervals for a month. Charles clicks through to a batch that had been frozen on a Sunday two weeks ago. A student who had only been in the laboratory to prepare an overnight antibody incubation, and who did not even use glioma cells in his work, had archived five vials of the cells. Charles checks the rest of the entries. At one time or another, each of his two postdocs and four students had frozen five vials of glioma cells, at or after 3 p.m. on the allotted day.

Charles is even more disturbed to note that nine of the vials have already been plucked from their sleep and moved on. One, Charles supposes, is now in Sweden, and another - one that Charles had believed to be seven years old, but that he now finds to be just seven days old — had gone for genome sequencing. This left seven that Charles couldn't account for. And somebody better be able to account for them by the time health and safety made their next audit.

The train jerks back into life and grinds into the station. An incomplete but disturbing hypothesis forming in his mind, Charlie pockets the computer and alights, just in time to miss a message from a postdoc.

$<$ esther > hi chuck, we've got a ${ }^{\star}$ big* problem here. someone has filled the incubators with glioma, and the whole lot are duds anyway. no one even admits to doing it. i think $i$ know what the problem is. it looks like you're gonna have to start from scratch. i'll keep some for troubleshooting, but i'm gonna have to start clearing out these incubators.

Now blinking in the sunlight, Charles ignores the cyclist gesturing at him as, still distracted, he shuffles across Oxford Street. On Tottenham Court Road he pushes a straight trajectory through the tourists. $\mathrm{He}$ trips in Bedford Square, taking the skin off one hand on the gravel, but does not stop to feel embarrassed.

At the Midwitch Institute on Gower Street, Charles is soon through the reception and up the concrete stairwell. He fumbles with his security card and crashes through the heavy doors to the lab, down a corridor cluttered with trolleys, tanks and barrels. He is too late. Charles has to push hard against the tissue culture room door to shift it, and the body behind. Esther, in a spreading pool of blood, two flasks in her left hand, a blade in the right.

Charles kneels in the vain hope of finding something he can do. Rising to leave and raise the alarm, he does not even notice himself step over the body, pry the flasks of glioma cells from the dead woman's hand, and place them neatly back in the crowded incubator, beside the dishes that he had ordered be destroyed two weeks earlier, closing the air-tight door behind them. So he was unable to explain to the court the presence of his footprint in the pool. Charles was loud and disruptive in court, but he settled into the routine at Broadmoor. After all, eight vials had got out. Soon the world would have to believe him.

Joe Dunckley once worked in cancer-cell biology, where he was never affected by cell-culture contamination. He blogs at Cotch.net and is excited about being paid to make stuff up. Join the discussion of Futures in Nature at http://tinyurl.com/kkh3kt 